\title{
The Disjuncture between Gendered Legislation and the Practice of Urban Planning: A Case Study of the Swaziland Urban Development Project
}

\author{
Hloniphile Y. Simelane*
}

\begin{abstract}
This study examines the disjuncture between gender-neutral legislation, state policies in particular, and the implementation of the Swaziland Urban Development Project (SUDP), an integrated development project co-funded by the World Bank and the Swaziland government. The project provided the opportunity to introduce gender-neutral land-related policies to improve women's access to land ownership in informal settlements. Using qualitative research methods and empirical evidence from the SUDP, this study assesses the environment in which patriarchal practices are reinforced. The study also advocates the formulation of gendered policies and a review of the institutions and structures underlying social relations and the control of resources. It argues that legislative measures alone are insufficient to improve the status of women in terms of land ownership. Finally, the study proposes the necessary policy conditions in which the SUDP's gender-neutral approach can effectively foster land redistribution.
\end{abstract}

\section{Introduction}

International development agencies and gender advocates acknowledge that women are generally disadvantaged by development projects and therefore, they recommend the formulation of gendered policies in development planning to improve the poor living conditions of women. In practice, however, as this study will demonstrate by recounting Swaziland's experience, development planning often does not actively promote the formulation of gender-sensitive or gender-neutral land policies or the

implementation of existing gender-neutral policies (Argarwal 1994; Moser 1993). In the few cases in developing countries where efforts have been made, studies have demonstrated the difficulty of implementing gendered legislation and gender-neutral policies meant to guarantee the protection of women against discrimination and exclusion in the control of resources such as land (Mapetla et al. 2007; Larsson et al. 2003). In this study, gender neutrality means taking cognisance of the prevalent gender-based division of resources and responsibilities in policymaking (Kabeer 1994) and development planning; whilst also disengaging from appropriate strategies to redress the gender imbalance in land ownership. Meanwhile, gender sensitivity can be defined as a tripartite process combining gendered policies, gendered strategies and their implementation with the intent to improve equity in land distribution. In the context of these definitions, the policies formulated under the Swaziland Urban Development Project (SUDP) can be considered gender-neutral, because the project failed to implement strategies that would work in the Swaziland gender-biased and patriarchal environment. In principle, gendered development planning should encompass both gender-neutral policies and strategies in order to ensure proper implementation (Moser 1993). However, development planning rarely complies with this principle. Gendered strategies include reviewing the institutions at the state, community and family levels that govern gender and power relations and harbour patriarchal tendencies. Patriarchy, a concept underpinning subordination of women, refers to institutional structures, which grant men the leverage to 


\section{Male guardianship}

During my meeting with traditional leaders to seek permission to conduct fieldwork, there was a discussion regarding whether I should be allocated a traditional leader who would accompany me whenever I conducted my interviews. The situation was saved by an old woman who opposed the idea, saying that people should be provided with an environment conducive to expressing their heartfelt thoughts without being intimidated by the presence of a leader. I attribute this challenge to the patriarchal nature of the society and my position as a female researcher rather than to security concerns. As uncomfortable and disappointing as the experience was, it helped me dismiss my assumption that my familiarity with the environment and my previous work relationship with the residents of Moneni would make fieldwork easier. I realised that for every interview, I had to be fully prepared for every eventuality.

\section{Controlling a male focus group}

During a focus group discussion, two younger participants challenged the authority of the elders over a statement made by one of the elderly men that the Moneni area had always been a good place, but this had since changed due to youngsters being disrespectful of the authorities. The youth were members of the Moneni Development Initiative (MDI), an association formed in 2008 mainly by the young people in Moneni that challenged the traditional leaders' style of leadership. Amongst their complaints in the focus group was that the youth of the area were not benefiting from the plot allocation process because the leadership was least concerned about them. This statement created tension between the youth and the older men which lasted for about ten minutes and highlighted the challenges I faced as a female researcher in the patriarchal society. One of the elderly men explicitly instructed me to wait and keep quiet until they had sorted it out, in essence challenging my role as the group's facilitator. I reluctantly complied with this instruction, as my mediation skills had not been successful, but I became anxious that some participants might decide to leave, which could be disastrous for my research. I was relieved when one participant shouted 'asichubeke nemsebenti make' (literally, 'madam let us now continue with the work'). These authoritative statements made by the participants who assumed the role of decision-makers were clear indications of traditional gender relations and reminded me of my assumed subservient position as a woman despite being a researcher. I was not only a female in a patriarchal society but also a relatively young researcher in a society where older women typically command more respect than younger women, as indicated in the above scenario where the female elder supported me concerning that I should be allowed to do fieldwork without being accompanied by a community representative. After this incident, I continued facilitating the discussion, but remained anxious that another dispute might arise, especially because the SUDP contained many contentious issues. I explained to the group again that the expression of different views was permitted as residents had been affected differently by the project, and I emphasised the need to respect different views. Thankfully, this seemed to work for some time.

yield power and influence over women physically, socially, relationally and economically. In most sub-Saharan societies, the status quo is perpetrated through customary land tenure systems (Goheen 1996; Whitehead and Tsikata 2003; Cotula et al. 2004). Certainly, gender imbalance and power relations in land ownership are rooted in the existing institutions supporting patriarchy. Those who benefit from the institutional rules, resources and practices which determine how authority and power are distributed strive to maintain the status quo (Kabeer 1994).

\section{Research methodology}

My interest in conducting this study developed during PhD fieldwork in September 2010; before then, gender issues did not form part of my priorities. Initially, I was puzzled by the recommendation that the Institute of 


\section{Categories}

SUDP Overseer

\section{Facts about the SUDP}

\begin{tabular}{ll} 
& Project covered two cities, namely Manzini and Mbabane \\
\hline Project time frame & Project began in the late 1980s - a baseline survey was conducted in 1988 \\
& The MHUD was established in 1991 \\
& Loan agreement between the Swaziland government and the World Bank was \\
& - Raise environmental health standards among urban low-income residents \\
\hline Objectives (MHUD 1993b; & Mobilise community resources and encourage participation in development \\
SUDP facts sheet n.d.) & Promote investment in urban employment opportunities \\
\hline Implementing and support & Manzini City Council, Mbabane City Council, Swaziland National Housing Board, \\
agencies & Swaziland Water and Services Corporation, Swaziland Electricity Board, Deeds \\
\hline Registry, Surveyor General & US $\$ 63.4$ million \\
\hline Residential upgrading project & $\begin{array}{l}\text { Although the loan agreement was signed in 1995, implementation of the } \\
\text { infrastructure services in Moneni only began in 2007. The reason for the delay was } \\
\text { contestation over the issue of authority between the traditional leaders and the } \\
\text { urban authorities. However, the plot allocation process was conducted } \\
\text { independently and began in the late 1990s }\end{array}$ \\
\hline
\end{tabular}

\begin{tabular}{|c|c|}
\hline $\begin{array}{l}\text { SUDP's uniqueness from } \\
\text { other projects }\end{array}$ & $\begin{array}{l}\text { 99-year lease introduced in the project areas (informal settlements) } \\
\text { Plot allocation policy and guidelines permitted land ounership by women } \\
\text { One of its components was an in situ upgrading project and no evictions were to } \\
\text { be carried out }\end{array}$ \\
\hline Profile of Moneni & $\begin{array}{l}\text { Traditional leaders: Senior Prince and Inner Council } \\
252 \text { households and a population of 1,745 when the project started (MHUD 1993a) }\end{array}$ \\
\hline Composition of the Plot & - Two representatives of the MHUD (one of them served as chairman) \\
\hline Allocations Committee & $\begin{array}{l}\text { In Moneni plot allocation meetings, Manzini City Council served as the secretariat, } \\
\text { two officials sat in the committee } \\
\text { Seven representatives of the community (in Moneni these were traditional } \\
\text { leaders), all appointed by the Senior Prince Manzini regional administration's } \\
\text { representative }\end{array}$ \\
\hline
\end{tabular}

Allocation policy/procedure

Moneni plot allocation list
- In 1994, the SUDP MHUD working group developed rules addressing questions such as: Who will allocate the plots? What is the process for the allocation of plots? What are the priority groups?

- In 1998, the Minister of Housing and Urban Development advertised the first plot allocation list in the print media in order to allow residents to lodge their objections. Traditional leaders stalled the plot allocation process at different intervals, such as 1998 and 2004, expressing dissatisfaction over the issue of authority. By May 2010, the plot allocation process was at an advanced stage and the list had been submitted to the minister for approval.
Development Studies' Research Committee made at my research outline seminar that the research should cover gender issues, especially how women were affected by the SUDP. Up to that point, I had assumed that there were no gender issues to be concerned with under the SUDP, because the Swaziland Ministry of
Housing and Urban Development (under pressure from the World Bank) had put in place the necessary gender policies. Such policies included a gender-neutral Plot Allocation Policy and guidelines, which I review in this article. To my surprise, however, my fieldwork exposed me to many gendered issues related to land tenure 
and planning of informal settlements. I realised then that the gender-neutral policies had brought about minimal change to the way that female residents of informal settlements were treated in land allocation, and the institutions and committees involved in managing the SUDP remained male-dominated.

In addition, my experience of gender discrimination as a female researcher, which differed from the treatment given to male researchers, was an experiential lesson on the challenges that women face in patriarchy. For instance, a male focus group subjected me to a gruesome 15-minute interview, disputing that I was an independent researcher, even though I had produced a document from my host university. In a state of panic that my focus group respondents might change their minds and refuse to participate, I supplied as much information as I could in order to convince them that I was indeed a valid researcher. This experience drew my attention to the reality of gender dynamics in Swaziland and thus prompted my interest in refocusing my research in a way which might inform future development policies and programmes, hopefully contributing to the transformation of patriarchal societies. It was after these and other experiences (see Box 1), that I began to meaningfully engage with gender literature and relate it to the SUDP. This period transformed my research to the extent that I dedicated an entire chapter of my $\mathrm{PhD}$ thesis to examining gender issues in urban development (see Simelane 2012). Ever since this period of fieldwork, I consider coverage of gender issues to be a component of research that is crucial for the development of Swazi society.

Data used in this study was collected during my $\mathrm{PhD}$ fieldwork, which I conducted from September 2009 to June 2010. Methods used included reviewing documents relating to the SUDP and land tenure in Swaziland, participant observation, semi-structured interviews with 40 key informants ${ }^{1}$ and a household survey. ${ }^{2}$ To gather the views of both women and men on how they have been affected by development projects, I conducted focus group discussions with women and men separately; this helped to reduce the confounding effect of the patriarchal society that had the potential to reduce the independent contribution of women. In spite of the fact that patriarchal tendencies thrive in Swaziland, I had the leverage to decide how much to conform to them, and partly due to being viewed as an outsider, I did not encounter much pressure. I only occasionally adhered to some aspects of patriarchal behaviour when it was necessary to enhance my acceptance in the community and avoid obstacles in data collection, such as during the male focus group discussion mentioned above.

\section{The SUDP and gender}

The SUDP was an integrated development project implemented in Manzini and Mbabane that had four components, namely: the expansion and rehabilitation of the citywide infrastructure; the upgrading of informal settlements situated on government-owned land in Manzini and Mbabane; policy and legislative reform; and institutional strengthening and capacity building (MHUD 1993a, 2008; World Bank 2002). This particular study was conducted in Manzini's informal settlement of Moneni, where an in situ upgrading project was piloted. A summary of the SUDP is provided in Table 1.

The significance of the SUDP's in situ upgrading project lay in the provision of plots through a 99-year lease, which was meant to enhance tenure security for women as well as men. ${ }^{3}$ With regard to land ownership, women are disadvantaged by both customary and statutory laws of the country. For instance, the Marriage Act 17/1964 and the Deed Registry Act 37/1968 treat married women as minors who cannot have property registered in their names (WLSA 1998; Ministry of Economic Planning and Development 2006; Thwala 2010). The assumption regarding the SUDP, therefore, was that the new tenure form would improve opportunities for women to hold land in terms of the 99-year lease. In addition, it was expected that security of tenure would result in increased investment. The Ministry of Housing and Urban Development (MHUD) also hoped that the 99-year lease would displace the customary land tenure arrangements in informal settlements, which undermined the urban authorities' (MHUD and city council) control over land in the area. Residents of these informal settlements had previously accessed land through the traditional leaders (Senior Prince and Inner council) who administer the customary tenure systems. Following the declaration of the areas as urban and the subsequent transfer of the land to the government, these traditional leaders ${ }^{4}$ were perceived as unofficial by the urban authorities. 


\begin{tabular}{|c|c|c|}
\hline Type of land & Ownership & Women's status \\
\hline $\begin{array}{l}\text { Category A Swazi Nation Land } \\
\text { (customary tenure system) }\end{array}$ & $\begin{array}{l}\text { Land owned by the King on behalf of } \\
\text { the nation and allocated by the chiefs }\end{array}$ & $\begin{array}{l}\text { Women need a male proxy to } \\
\text { access this land }\end{array}$ \\
\hline $\begin{array}{l}\text { Category B Freehold land (statutory } \\
\text { land tenure system) }\end{array}$ & $\begin{array}{l}\text { Privately owned land/title deed (private } \\
\text { plots, commercial farms and ranches) }\end{array}$ & $\begin{array}{l}\text { Single women can obtain title } \\
\text { independent of men but forfeit } \\
\text { ownership if they get married in } \\
\text { community of property } \\
\text { Married women cannot own land } \\
\text { if married in community of } \\
\text { property }\end{array}$ \\
\hline Category C Crown Land & $\begin{array}{l}\text { In urban areas, the Ministry of Housing } \\
\text { and Urban Development oversees } \\
\text { crown land on behalf of the King } \\
\text { In rural areas, crown land is } \\
\text { controlled by different ministries, } \\
\text { but this does not include land } \\
\text { owned by institutions such as } \\
\text { Tibiyo Takangwane and Tisuka } \\
\text { TakaNgwane }\end{array}$ & $\begin{array}{l}\text { Plots can be allocated to women, } \\
\text { but married women cannot } \\
\text { register plots independently of } \\
\text { their husbands }\end{array}$ \\
\hline $\begin{array}{l}\text { Category D Land administered } \\
\text { under the SUDP with a 99-year } \\
\text { lease }\end{array}$ & $\begin{array}{l}\text { The holder of the title deed is given } \\
\text { the land for } 99 \text { years and has user rights } \\
\text { but does not officially own the land }\end{array}$ & $\begin{array}{l}\text { In principle, women and men are } \\
\text { permitted equal access to land }\end{array}$ \\
\hline
\end{tabular}

The urban authorities also considered informal settlement residents to have illegal status, one possible reason for the poor implementation of the SUDP's gender-neutral policies.

Contrary to the perceptions discussed above and the thriving patriarchal practices, the Government of Swaziland, the World Bank and other international organisations ${ }^{5}$ that provided technical support ${ }^{6}$ identified the need to address the issue of women's access to plots during the planning and project preparation phases of the SUDP in the early 1990s. These participating organisations assisted in the drafting of specific policies, such as the Peri-urban Growth Policy, Plot Pricing Policy, Allocation Policy and Resettlement and Compensation Policy (Lowsby and De Groot 2007). In order to explore the gendered dimension of this project, the analysis below will focus mainly on how the Plot Allocation Policy and guidelines stipulating plot categories and beneficiaries were made gender-neutral and how they were implemented. As discussed in the above paragraph, married women are disadvantaged not only by customary laws, but also by the statutory laws of the country, which consider them as minors who cannot have property registered in their names (WLSA 1998; Daly 2001; Thwala and Dlamini 2003; Thwala 2010). From a development perspective, this is a concern, given that 39.7 per cent of households in Swaziland are female-headed and 63 per cent of these female heads of household are poor and lack productive assets (Ministry of Economic Planning and Development 2006). Table 2 gives insight into the land tenure system in Swaziland, demonstrating the position of women and their need to rely on men to secure access to land ownership.

Given the status of women in relation to land control as indicated in Table 2, it is likely that without the World Bank's involvement, genderneutral policies would not have been formulated for Moneni and other informal settlements. There are three reasons for making the assertion. Firstly, Moneni had been administered using customary law since Swaziland's independence (key informants 2009), and the customary land tenure system restricts women from accessing land in the absence of a proxy (Armstrong and Nhlapho 1985; Rose 1992; Thwala 2010). Secondly, during fieldwork, both 


\begin{tabular}{|c|c|c|}
\hline $\begin{array}{l}\text { Stages of plot } \\
\text { allocation }\end{array}$ & Responsibilities of plot beneficiaries & Opportunities/problems for women \\
\hline Census & $\begin{array}{l}\text { Register the head of family and other } \\
\text { family members }\end{array}$ & $\begin{array}{l}\text { Married women only considered head of } \\
\text { household if their husband was deceased }\end{array}$ \\
\hline $\begin{array}{l}\text { Lodging of objections } \\
\text { regarding the list of } \\
\text { allottees advertised } \\
\text { by the MHUD }\end{array}$ & $\begin{array}{l}\text { Submit objections to the Secretariat } \\
\text { (Manzini City Council) }\end{array}$ & $\begin{array}{l}\text { Women had the opportunity to object but their } \\
\text { objections were impeded by patriarchal practice } \\
\text { (see explanation below) }\end{array}$ \\
\hline $\begin{array}{l}\text { Allottees shown plot } \\
\text { boundaries }\end{array}$ & $\begin{array}{l}\text { Be present and participate in the } \\
\text { exercise }\end{array}$ & $\begin{array}{l}\text { If the household head was a male, women } \\
\text { would only be involved at the mercy of the head } \\
\text { of the household }\end{array}$ \\
\hline $\begin{array}{l}\text { Payment of } \\
\text { commitment fee }\end{array}$ & $\begin{array}{l}\text { Pay E400 (400 emalangeni) as a } \\
\text { commitment fee and deposit }\end{array}$ & $\begin{array}{l}\text { Women who had been allocated plots had to } \\
\text { pay the commitment fee }\end{array}$ \\
\hline $\begin{array}{l}\text { Signing of deed of } \\
\text { sale, } \\
\text { Pay plot price and } \\
\text { receive title deed }\end{array}$ & $\begin{array}{l}\text { Sign the deed of sale } \\
\text { Receive 99-year lease title }\end{array}$ & $\begin{array}{l}\text { Women who were allocated plots were to be } \\
\text { granted the deed of sale and ultimately the } \\
\text { 99-year lease when the plot price was settled }\end{array}$ \\
\hline
\end{tabular}

MHUD and Manzini City Council (MzCG) officials insisted that the residents of the informal settlement of Moneni were illegal and therefore not entitled to plot allocation or compensation. They asserted that the MHUD only agreed to allocate them plots out of courtesy; otherwise, the residents could have been evicted (key informants 2009). Thus, even if the traditional leaders had consented to genderneutral policies, the MHUD might not have considered policies to enhance women's ownership of property. Thirdly, the inclusion of the gender component in the SUDP required investment in the formulation of policies such as the National Housing Policy, the draft land policy and plot allocation criteria, all of which had cost implications. Since gender issues are not a priority for policymakers, investment in them would not be a priority either.

The passive approach taken towards the implementation of the gender-neutral policies shows an overall lack of concern for gender issues. Confirming this, other projects that had been implemented in the country prior to the SUDP did not pay much attention to gender issues either. For instance, the Rural Development Areas Programme (RDAP), intended to enhance land development, marketing and social services, failed to address women's needs (Miles 2000). Even in the urban context, the low-income housing projects implemented by the Swaziland National Housing Board to address the challenge of rural-urban migration in post-colonial Swaziland did not establish strategies to address gender imbalance. Given that 43 per cent of households in Swaziland's informal settlements are femaleheaded and the World Bank's loan mandated the inclusion of vulnerable groups such as women, it would have been inappropriate for the SUDP development planners to totally neglect the inclusion of gender-neutral policies. As observed by Young (1993), policymakers in developing countries often require directives and pressure to address women's rights - in this case, the conditions attached to the World Bank loan.

\section{Plot allocation process}

Before the 99-year lease titles that were part of the SUDP could be issued, the complex plot allocation process needed to occur. This process triggered sociopolitical dynamics such as resistance from the Moneni traditional leaders who, contrary to the expectations of the urban authorities, ultimately controlled the process. Reluctant to relinquish jurisdictional authority to the urban authorities, the traditional leaders asserted that the land in question was Swazi Nation Land, the control of which rested with them and not with the urban authorities. Consequently, the process was stalled by questions of authority and control in 1998 and 2004, and plot allocation ended up occurring in 
different phases (see Simelane 2012 for detailed information on the sociopolitical dynamics leading to the stalling of the project). Table 3 presents the steps which women (and men) were supposed to follow in order to be allocated land. This study focuses on the Plot Allocation Policy and guidelines in order to analyse the complexities involved in implementing the SUDP's genderneutral policies and assess the space in which patriarchal tendencies were reinforced. Since the plot allocation process had not been completed when fieldwork ended in June 2010, the analysis is based on the draft plot allocation list which was provided by the MHUD to the Community of Moneni through their leaders and the print media. Additional data was also collected from primary documents such as the Plot Allocation Committee's minutes and participant observation to investigate, for instance, the reasons behind the allocation of plots to certain women.

The plot allocation process was meant to be equitable, transparent and simple to understand. With regard to equity, women were supposedly entitled to a fair share of the land. In an effort to ensure fairness, the allocation policy specifically stated that women were eligible to receive plots, meaning that men and women were supposed to have equal access to plots (SUDP Plot Allocation Policy 1994). For instance, the guidelines stipulated that beneficiaries of plots included the following categories: female heads of households, daughters and women in polygamous relationships. Despite the policies, however, the allocation process did not make women a priority, except in a few circumstances discussed in the next section. The SUDP is another case study that demonstrates the difficulty of implementing gender-neutral legislation and policies.

The Plot Allocation Policy also stipulated that once the allocation list (which detailed who was eligible to receive land and what their respective plot numbers were) had been compiled by the Plot Allocation Committee, it had to be advertised in the printed media to enable residents to lodge their objections with the MHUD (SUDP Plot Allocation Policy 1994). In my fieldwork, I found that most of the objections came from men. This does not mean that women did not have objections, but rather that Swazi women are subordinated in a patriarchal society. There are three main factors that might possibly have discouraged women from objecting: (1) women were intimidated and ill prepared to fight against the discrimination they faced in the distribution of land; (2) women were dissuaded by the fact that the allocations committee included traditional leaders whom they knew were custodians of customary patriarchal practices; and (3) women might have been discouraged by the tedious complaints process, which was time consuming and unmanageable given their triple role (reproductive, productive and community management related) discussed in Moser's study (Moser 1993).

In the few instances where women did lodge objections regarding the Moneni plot allocation list, patriarchy manifested itself in several ways. Firstly, the objections were deliberated by a Plot Allocation Committee that was male-dominated, with only one female representative (the composition of the committee is analysed later in this article). According to Swazi custom, in the event that the owner of a homestead dies, the first-born male child normally becomes the undisputed head of the homestead and administers the inheritance on behalf of his siblings. Given this practice, in most cases where complaints were lodged by women, the decisions made did not favour the aggrieved women. Secondly, women who lodged complaints were sometimes advised by the members of the Plot Allocation Committee to discuss the issue with their family first and only seek intervention from the committee if the issue could not be resolved. Paradoxically, these family members referred to in this context normally include brothers, uncles and fathers who are generally the decisionmakers. Decisions made by a family regarding a dispute had to be submitted in the form of a letter signed by the family, and these letters tended to influence the decisions of the Plot Allocation Committee. Thirdly, in order to respond to the objections, the Plot Allocation Committee required a written resolution from the Community Inner Council, whose head was a Senior Prince, with powers almost equivalent to those of the area's chief - some subjects even referred to him as chief. This committee served as a custodian of customary and thus patriarchal, practices, suggesting that it would not promote land ownership by women. The operations of the Plot Allocation Committee, therefore, were grounded on Swazi customs and patriarchal traditions. 
The research identified four main gender-related problems with the plot allocation system, namely that it: (1) excluded women who had acquired access to land through informal means because plots were allocated to official heads of households; (2) excluded adult daughters; (3) favoured women in polygamous marriages; and (4) lacked female representation in the institutional structures set up to deal with the SUDP. Each of these gender-related problems is discussed in detail below.

\subsection{Plots allocated to official heads of households (khonta)}

The first gender-related problem of the plot allocation process is that it only considered existing heads of households who had acquired land through khonta (settled through arrangement with traditional leaders) ${ }^{7}$ or had 'purchased' land from the Senior Prince, thus excluding many women who had access to land through other unofficial channels. For instance, five women who had unofficially received permission to build structures on a piece of land owned by a widow complained that they were being left out of the plot allocation exercise, despite having stayed in Moneni for several years - some for more than 20 years (interviews, key informants 2009). The reason provided by the traditional leadership, whose opinions informed the Allocations Committee, was that these women, and others in similar positions, had not followed the proper process for settling in the area and had not paid the khonta fee, and thus they could not be treated as residents of Moneni (interviews 2009; key informants 2009). They were instructed to pay the khonta fee if they wished to become eligible for plot allocation, but most of them could not afford this fee. As a result, these women were threatened with exclusion from the allocation list, and some of them expressed uncertainty about their future in Moneni during the focus group discussions (focus group 2010). In this focus group, the women were quite open in expressing their feelings and opinions, deepening my understanding of the negative impact that development projects can have on women. This was clear cut discrimination against women, as the traditional leaders had not threatened the men who had not paid the settlement fee. Clearly, considering only existing heads of households and those who had gone through the khonta process excluded women who had used unofficial channels to access land.
In the end, though, some women were granted plots. Although the plot allocation process in Moneni has dragged on for more than a decade, ${ }^{8}$ the draft plot allocation list of 2007 shows that out of the 283 people who had been provisionally allocated plots, 63 (22 per cent) were women. According to Swazi custom, males are expected to be heads of homesteads. However, the Moneni traditional leaders did make an effort to recommend that plots be allocated to women whose husbands had died, and this recommendation was not contested by the Plot Allocation Committee (key informants 2009; household survey 2009). This resulted in a number of widows receiving plots, thereby improving their circumstances. Thus, change in institutional processes can help to improve women's status in society.

Although 22 per cent of the allottees were women, this percentage is quite low, and it depicts women's marginalisation in land reorganisation exercises, despite the SUDP's intent to address gender issues. The marginalisation of women in land redistribution was similarly observed in Kenya's privatisation programme, in which only 7 per cent of the registered rights-holders were women (Mackenzie 1990). Likewise, in Masvingo Province in Zimbabwe, land allocation processes favour the allocation of land to men (Scoones et al. 2010). These other examples show that discrimination against women in land distribution is a regional phenomenon, but it does not neglect the inadequate effort made by the MHUD and Manzini City Council officials to persuade the traditional leaders not to exclude these women, as it was against the principle of the SUDP and the World Bank to evict residents. By the end of the fieldwork in 2010, the traditional leaders continued to insist that all residents in Moneni must pay the khonta fee, as it would not be fair to those who had already paid the fee to allocate plots to those who had not paid (Moneni Plot Allocation Committee 2010). A survey of 25 female heads of household in Moneni revealed that in the process of obtaining permission from the traditional elders to settle in the area, ten of them were assisted by their relatives, five were helped by community members not related to them, nine received no help, and the last participant did not answer the question.

\subsection{Exclusion of adult daughters}

The second gender-related problem concerning the plot allocation process is that very few 
families requested that plots be allocated to their daughters. Plots were generally allocated to the male head of the household or the eldest son, and in the distribution of extra plots, other sons were given priority over daughters. Even in instances where adult daughters were heads of households, it was difficult for them to receive plots due to their brothers' objections. Objections made regarding the plot allocation list published by the MHUD revealed some of this conflict between brothers and sisters. Thus, the fact that the SUDP did not use gendered concepts or language to determine plot criteria and allocations meant that, for the most part, sons were allocated the additional plots. Single women were even more vulnerable, especially women who did not have good relationships with their male relatives. Male family members resisted the issuance of a 99-year title to women because as titleholder, the women would have the right to take decisions that best suit them. Women who have a falling out with their brothers risk being evicted from their parental homes and being rendered homeless. Similarly, the new plot allocations placed some women at risk of eviction, particularly if they were on bad terms with their natal families. Nonetheless, a few plots were allocated to women whose brothers were considered irresponsible and not economically productive. For instance, adult sons who were drunkards and without a source of income had only a slim chance of being allocated a plot, as they would not be able to pay the commitment fee and plot price (interviews 2009/10).

\subsection{Women in polygamous marriages favoured}

Although the plot allocation criteria favoured women in polygamous marriage, bias against the women in plot allocation manifested. A few husbands demanded to have all plots registered in their name rather than in the name of one of their wives. Some men in polygamous marriages considered their wives to be equivalent to children, and thus not entitled to plot allocation, as illustrated by the case of Mr Dlamini.

\section{Mr Dlamini used to be a member of the Inner} Council and served in important leadership structures of the Moneni community, including the Plot Allocation Committee. When the time came to allocate plots to his family, he adamantly rejected the proposal that the plot on which his second (childless) wife's house stands be allocated to her. Other members of the Allocations
Committee made efforts to get him to consent to allocating this plot to his wife; instead, he asserted that the plot should rather be allocated in the name of his first wife's son. However, the committee contested this because the son was not the second wife's biological child, and he might decide to chase her away. The second wife was ultimately allocated the land against the will of Mr Dlamini, who contended that the allocation was causing friction among his 'children' and creating division in his family (interviews, Gity Council minutes, personal information, 2009). He insisted that once the allocation process had been finalised, he would apply for permission to effect a consolidation $^{9}$ of the plots to correct what he considered an anomaly.

The fact that Mr Dlamini referred to his wives as children is a cause for concern, as it further illustrates the minority status accorded to women in Swaziland. It is obvious that he did not see his wife as being capable of administering her household without his leadership or that of his son, and he regarded the allocation of a plot in his second wife's name as a threat to the unity of his family. However, the second wife refuted the alleged family unity and lobbied members of the Moneni Plot Allocation Committee for a plot (key informants, personal information). She contended that she needed a separate plot to avoid property-related conflict between her and the first wife or the first wife's children in the future, especially after the husband died. The husband's framing of the issue could be seen as an instrumental strategy meant to block his wife from independently owning property. This scenario demonstrates that though the plot allocation system may end up maintaining and reinforcing traditional male dominance over land (Toulmin and Quan 2000; Mapetla et al. 1998), in this case, the committee overruled the husband and his wife got the plot.

\subsection{Lack of female representation in institutional structures}

Urban planning structures often fail to recognise the importance of patriarchal power relations in communities (Marshall et al. 2009). As a result, women are at a disadvantage and have to compete with the powerful male individuals that dominate the structures, institutions and laws of urban space (Mapetla et al. 1998). Given this reality, a fourth gender-related problem regarding the implementation of the SUDP was 
that the project's political and administrative structures were all male-dominated, having almost zero representation of women. The maledominated Moneni Steering Committee ${ }^{10}$ for instance, played a crucial role in plot allocation under the SUDP. It approved heads of household for land distribution and resolved land-related disputes, including those between families and neighbours. This seven-member committee was comprised solely of males until one female member was appointed in 2008. Even after a female was appointed to the committee, she lacked the support needed to advocate for the distribution of land to women. The sole female member stated that she had fruitlessly tried to explain to the other committee members that the number of single mothers had increased and that single women therefore needed to be allocated plots. Despite her attempts, the male Moneni elders on the committee unfairly clung to the tradition and resisted allocating plots to single women (informal communication 2009).

Not only were the committees male-dominated; the managers, planners, engineers and other technicians involved in the planning and implementation of the project were almost all men - only two project officials were women. Granted, one of these women was the head of the Planning Department responsible for coordinating the project in Moneni, and thus participated in major policy decisions. The fact that men greatly outnumbered women may be part of the reason why the SUDP's gendered policies were not fully implemented. ${ }^{11}$ It also calls into question the commitment of not only the government and urban authorities, but the entire project team in advancing the interests of women in land distribution and development in general. Indeed, men in Africa have the right to go before the formal apparatus of state to make claims to land (Gray and Kevane 1999), but women do not. The exclusion of women from these structures and processes was the beginning of the SUDP's failure to address women's land tenure security. As pointed out earlier in the article, the formulation of gendered legislation without the creation of better strategies leads to poor implementation, and this is what happened with the SUDP. It is the same as creating a man's world and then asking the men to improve the position of women. This is unworkable, because improving the position of women would threaten the privileged position of men, and men do not want this to happen.

\section{Conclusion}

The research presented in this article demonstrates that gender-neutral policies that promote equality in land distribution are ineffective in the absence of suitable strategies and the commitment to implement them effectively. The SUDP plot allocation process in Swaziland has only marginally improved women's land ownership in the project area. The patriarchal practices continue to exclude women from land ownership, leaving most women disadvantaged and uncertain about their future. Furthermore, the study illustrates the ineffectiveness of male-dominated institutional and political structures in improving female land ownership. Various institutions and processes involved in the SUDP land redistribution exercise discriminated against and reinforced the subordination of women.

The study also shows that it is not just traditional structures that resist gender-neutral approaches to urban planning. The urban authorities, while perhaps not as overtly resistant as the traditional structures, nonetheless remained passive regarding gender-neutral policies. They did not establish mechanisms to promote the implementation of the genderneutral Plot Allocation Policy and guidelines, nor did they monitor the plot allocation process to ensure that it was gender-neutral.

The research proposes, therefore, that urban development planning should not only formulate gender-neutral policies, but should also review and transform the patriarchal institutions and processes that lead to male domination of land ownership. This requires commitment from the government and urban authorities, as it is a longterm process that will have cost implications, provoke resistance from the beneficiaries of the status quo (men) and may involve the review of urban legislation. Finally, the disjunction between the gender-neutral Plot Allocation Policy and its implementation requires further investigation to reveal the long-term effects that could not be captured immediately before and after project completion. 


\section{Notes}

* The author would like to thank Dr Linda Waldman, a Research Fellow at IDS, for her contributions to the article. The author would also like to extend appreciation to the African Centre for Migration and Society at the University of the Witwatersrand for permitting her to affiliate with them in April 2013, thus enabling her to have access to the literature needed to write this article. This research also benefited from the input of Professor Mfaniseni Sihlongonyane and Professor Marie Huchzermeyer, associate professors at the University of the Witwatersrand's School of Architecture and Planning, and Professor Marvellous Zhou, associate professor at the University of the Free State. Finally, special thanks go to the reviewers who made valuable comments on the work.

1 These informants were government officials, council officials, traditional leaders and community representatives who participated in the SUDP.

2 I carried out this survey with 50 heads of households, 25 of whom were female.

3 The 99-year lease is a form of tenure that involves the conversion of government-owned land or Swazi Nation Land to leasehold. The MHUD administered the distribution of land to beneficiaries, who only had to pay for the cost of service provision.

4 Nevertheless, these traditional leaders became members of the Plot Allocation Committee, along with representatives from the MHUD and the Implementing Agency (the Swazi National Housing Board up until 2002 and thereafter the Manzini City Council).

5 These other organisations included the United Nations Development Programme (UNDP), the Department for International Development

\section{References}

Argarwal, B. (1994) A Field of One's Own: Gender and Land Rights in South Asia, Cambridge: Cambridge University Press

Armstrong, A.K. and Nhlapho, R.T. (1985) Law and the Other Sex: The Legal Position of Women in Swaziland, Mbabane: Websters Publishers

Cotula, L.; Hesse, C. and Toulmin, C. (2004) Land Tenure Administration in Africa, London: International Institute for Environment and Development (IIED)

Daly, J.L. (2001) 'Gender Equality Rights Versus Traditional Practices: Struggles for Control
(DFID) and the United States Agency for International Development (USAID).

6 Technical support included advisory support to the implementing agencies' engineering and finance departments, environmental management, reviews of land-related legislation, provision of long-term training to urban planners and a surveyor, training on project management and technical support to the Project Coordination Unit.

7 Khonta (settled through arrangement with traditional leaders); in Moneni, women received land through the assistance of a male relative proxy.

8 Mainly due to the reluctance of the traditional authorities to assume a position subservient to the urban authorities and forgo any authority over the administration of the area $-\mathrm{a}$ privilege enjoyed for many decades.

9 The Town Planning Act of 1961 permits the consolidation of two or more separate plots into one plot. This is done, for example, by developers who need a larger piece of land for their planned business development. In this case, Mr Dlamini announced that he would apply to register all the plots in his name (interview 2009 and personal communication 2009).

10 The Moneni Steering Committee originally consisted of seven men who were appointed by the traditional leaders to represent the community on the Plot Allocation Committee. It was only in 2008 that one female member was appointed to the committee.

11 This gender bias is also reflected in the number of political positions held by Swazi women at the national level. For instance, the proportion of seats occupied by women in parliament is only 22 per cent (UNDP 2012).

and Change in Swaziland', Development Southern Africa 18.1: 45-6

Goheen, M. (1996) Men Own the Fields, Women Own the Crops, Madison WI: University of Wisconsin Press

Gray, L. and Kevane, M. (1999) 'Diminished Access, Diverted Exclusions: Women and Land Tenure in Sub-Saharan Africa', African Studies Review 42.2: 15-39

Kabeer, N. (1994) Reversed Realities: Gender Hierarchies in Development Thought, New York: Verso

Larsson, A.; Mapetla, M. and Schlyter, A. (2003) Gender and Urban Housing in Southern Africa: 
Emerging Issues, Roma: The Institute of Southern African Studies

Lowsby, J. and De Groot, D. (2007) A Brief History of Urban Development and Upgrading in Swaziland, Mbabane: Ministry of Housing and Urban

Development

Mackenzie, F. (1990) 'Gender and Land Rights in Muranga District, Kenya', Peasant Studies 17.4: $609-43$

Mapetla, M.; Lassorn, A. and Schlyter, A. (1998) Changing Gender Relations in Southern Africa: Issues of Urban Life, Roma: Institute of Southern African Studies

Mapetla, M.; Schlyter, A. and Bless, B.D. (2007) Urban Experiences of Gender Generations and Social Justice, Roma: Institute of Southern African Studies

Marshall, F.; Waldman, L.; MacGregor, H.; Mehta, L. and Randhawa, P. (2009) On the Edge of Sustainability: Perspectives on the Peri-Urban Dynamic, STEPS Working Paper 35, Brighton: STEPS Gentre

MHUD (2008) Final Report: Urban Development Project Evaluation, Vol. 1, Mbabane: Ministry of Housing and Urban Development

MHUD (1998) Impact of the Urban Development Project on Property Rights, a Working Paper Produced by the Gender Perspectives Working Group, Mbabane: Ministry of Housing and Urban Development MHUD (1994) SUDP Plot Allocation Policy, Mbabane: Ministry of Housing and Urban Development MHUD (1993a) Swaziland Urban Development Technical Report 1, Vol. 1, Mbabane: Ministry of Housing and Urban Development

MHUD (1993b) Urban Development Project Overview: Technical Report 2-Volume 1, Swaziland Urban and Industrial Infrastructure Project, Phase II-Project Preparation Consultancy, Mbabane: Ministry of Housing and Urban Development

Miles, M. (2000) 'Urbanisation in Swaziland: A Post-Independence Assessment of its Implications on the Changing Role of Women', Urban Forum 11.1: 103-18

Ministry of Economic Planning and Development (2006) Poverty Reduction Strategy and Action Programme, Volume 1, Mbabane: Ministry of Economic Planning and Development Moneni Plot Allocation Committee (2010) Minutes of Plot Allocation Meeting, 6 October, Manzini: Manzini Gity Council Moser, G.N. (1993) Gender Planning and Development: Theory, Practice and Training, London and New York: Routledge
Rose, L. (1992) Politics of Harmony: Land Disputes Strategies in Swaziland, New York: Cambridge University Press

Scoones, I.; Marongwe, N.; Mavedzenge, B.; Mahenehene, J. and Sukume, C. (2010) Zimbabwe's Land Reform: Challenging the Myths, Harare: Weaver Press

Simelane, H.Y. (2012) 'The Interplay of Urban Land Tenurial Systems and its Effects on the Poor: A Case Study of Manzini in Swaziland', PhD thesis, Brighton: University of Sussex SUDP Facts Sheet No. 1 (n.d.), Mbabane: MHUD Swaziland Urban Development Project (SUDP) (1994) Factsheet No.2: Allocation Criteria and Procedures, Mbabane: MHUD

Thwala, P. (2010) 'Gender Mainstreaming in Swaziland: Issues and Lessons Learnt', in M. Tadesse and A. Daniel (eds), Gender Mainstreaming Experiences from Eastern and Southern Africa, Addis Ababa: Organization for Social Science Research in Eastern and Southern Africa (OSSREA)

Thwala, P. and Dlamini, P. (2003) Gender and Land Issues, Mbabane: UNDP and Ministry of Housing and Urban Development (MHUD)

Toulmin, C. and Quan, J. (eds) (2000) Evolving Land Rights, Policy and Tenure in Africa, London: International Institute for Environment and Development (IIED)

UNDP (2012) Complementary Country Analysis: The Kingdom of Swaziland, Mbabane: United Nations Development Programme

Whitehead, A. and Tsikata, D. (2003) 'Policy

Discourses on Women's Land Rights in Sub-Saharan Africa: The Implications of the Re-turn to the Customary', Journal of Agrarian Change 3.1-2: 67-112

WLSA (1998) Family in Transition: The Experience of Swaziland, Mbabane: Women and Law in Southern Africa Research and Educational Trust Women in Law and Development in Africa (2001) The Legal Status of Women in Swaziland: A Compilation of the Laws of Swaziland and their Impact on Women, Mbabane: Coordinating Assembly of Non-Governmental Organizations (CANGO)

World Bank (2002) Upgrading Low-Income Settlements: Country Assessment Report, World Bank Strategy and Action Programme, Mbabane: Ministry of Economic Planning and Development

Young, K. (1993) Planning Development with Women: Making a World of Difference, London: Palgrave Macmillan 